\title{
Auxinic herbicides induce oxidative stress on Cnesterodon decemmaculatus (Pisces: Poeciliidae)
}

\author{
Celeste es Ruiz de Arcaute ${ }^{1,2}$ - Natalia A. Ossana ${ }^{2,3}$ • Juan Manuel Pérez-Iglesias ${ }^{1,2}$ - Sonia Soloneski ${ }^{1,2}$. \\ Marcelo L. Larramendy ${ }^{1,2}$
}

Received: 20 December 2018 / Accepted: 11 April 2019 / Published online: 17 May 2019

(C) Springer-Verlag GmbH Germany, part of Springer Nature 2019

\begin{abstract}
Pesticides might increase the production of reactive oxygen species (ROS). Dicamba (DIC) and 2,4-dichlorophenoxyacetic acid (2,4-D) are auxinic herbicides commonly applied in agroecosystems to control unwanted weeds. We analysed the oxidative damage exerted on the fish Cnesterodon decemmaculatus by an acute exposure to DIC- and 2,4-D-based herbicides formulations Banvel $^{\circledR}$ and DMA ${ }^{\circledR}$, respectively. The Endo III- and Fpg-modified alkaline comet assay was employed for detecting DNA damage caused by oxidative stress, whereas enzymatic and non-enzymatic biomarkers such as the activities of catalase (CAT), glutathione-S-transferase (GST), acetylcholinesterase (AChE), and glutathione content (GSH) were used to assess antioxidant response to these two herbicides. At the DNA level, results demonstrate that both auxinic herbicides induce oxidative damage at purines level. An increase on CAT and GST activities were detected in $48 \mathrm{~h}$ - and $96 \mathrm{~h}$-treated specimens with both auxinics. GSH content decreased in fish exposed to DIC during $48 \mathrm{~h}$ and to 2,4-D after $96 \mathrm{~h}$ of exposure. Additionally, a diminished AChE activity in specimens treated with DIC and 2,4-D was observed only after $96 \mathrm{~h}$. Total protein content decreased in fish exposed to both auxinics during $96 \mathrm{~h}$. These results represent the first evaluation of oxidative damage related to DIC and 2,4-D exposure on a fish species as the Neotropical freshwater teleost C. decemmaculatus.
\end{abstract}

Keywords Endo III- and Fpg-modified comet assay $\cdot$ Catalase $\cdot$ Glutathione $\cdot$ Glutathione-S-transferase $\cdot$ Acetylcholinesterase

\section{Introduction}

The effectiveness of pesticides, together with their massive use at a global scale, has rendered these chemicals a major issue for inducing environmental pollution (Lazartigues et al. 2013). These xenobiotics eventually reach and pollute air, soil, and water compartments, where herbicides represent an important fraction within the aquatic environmental stressors (Liaud et al. 2016; Meffe and de Bustamante 2014). Among

Responsible editor: Cinta Porte

Marcelo L. Larramendy

marecelo.larramendy@gmail.com

1 Cátedra de Citología, Facultad de Ciencias Naturales y Museo, Universidad Nacional de La Plata, Calle 64 Nro. 3 (esq. 120), B1904AMA La Plata, Argentina

2 Consejo Nacional de Investigaciones Científicas y Técnicas (CONICET), Buenos Aires, Argentina

3 Programa de Ecofisiología Aplicada, Instituto de Ecología y Desarrollo Sustentable (PRODEA-INEDES), Universidad Nacional de Lujan, C.C. 221, Luján, Argentina the latter group are included dicamba (DIC, 3,6-dichloro-2methoxybenzoic acid) and 2,4-dichlorophenoxy acetic acid (2,4-D), auxinic chemicals extensively employed to manage pre- and post-emergent weeds (USEPA 2017). Furthermore, these herbicides fall within the top ten agrochemicals employed in Argentina (CASAFE 2017).

DIC is part of the benzoic acid chemical family (USEPA 2006) and 2,4-D belongs to the phenoxy alkanoic acid family of herbicides (USEPA 2005). Several genotoxic studies have been performed in different biotic matrices to assess the genotoxic effects induced by both DIC and 2,4-D. Among them, induction of sister chromatid exchanges (SCEs) (Arias 2007; González et al. 2006; Madriagal-Bujaidar et al. 2001), micronuclei (MNs) (Ateeq et al. 2002; Farah et al. 2006; González et al. 2011; Ruiz de Arcaute et al. 2014b), and DNA strand breaks by the comet assay (Ateeq et al. 2005; Bokán et al. 2013; González et al. 2005, 2007; Martínez-Tabche et al. 2004; Ruiz de Arcaute et al. 2014b; Sorensen et al. 2005). Furthermore, it has been demonstrated that 2,4-D induced chromosomal aberrations (Adhikari and Graver 1988; Amer and Aly 2001; Farah et al. 2006). 
Environmental pollutants, including herbicides among others, are known to cause oxidative damage in exposed organisms to them by increasing the production of reactive oxygen species (ROS) (Atamaniuk et al. 2013; Cadet et al. 2003). Organisms have enzymatic and non-enzymatic mechanisms to balance the production and undesirable effects of ROS (Lushchak 2011; Valavanidis et al. 2006). Whether natural cellular pro-oxidants exceed the antioxidants cellular production could result in oxidative stress (Cooke et al. 2006; Valko et al. 2006). Additionally, ROS could interact with macromolecules leading to lipid peroxidation, enzyme inactivation, hormone oxidation and jeopardize DNA (Cavalcante et al. 2008; Newman and Clements 2008).

In the last decade, the usefulness of a battery of biomarkers to detect and quantify pesticide-induced deleterious effects on target and non-target species is a welldocumented aspect in ecotoxicological investigations. Among them, the comet assay is a frequent and recommended test to detect DNA damage in different organisms, including fish (Bony et al. 2010; Martins and Costa 2017). The comet assay, either in its alkaline and neutral version, detects several DNA lesions such as single- and doublestrand breaks as well as alkaline-labile sites (Dhawan and Anderson 2017). Nevertheless, the addition of lesionspecific endonucleases in the methodology will introduce DNA breaks at the damaged bases these restriction enzymes identify, giving information, then, about the type of lesion induced. Consequently, the modified comet assay could be considered as a valuable and sensitive method to estimate oxidative damage in genotoxicological evaluations (Azqueta et al. 2017; Collins and Azqueta 2012; Pérez-Iglesias et al. 2017). Briefly, after the lysis period of the conventional comet assay methodology, a digestion with lesion-specific endonucleases is included. Two examples of the aforementioned endonucleases commonly employed are the formamidopyrimidine-DNA glycosylase (Fpg) and endonuclease III (Endo III) (Collins 2004; Collins et al. 1996). Fpg identifies and eliminates damaged purines from DNA, e.g. 8-oxoguanine, Fapy-Gua, Fapy-Ade, and to a lesser extent 8-oxoadenine. On the other hand, Endo III transforms oxidized pyrimidines into strand breaks.

The most studied enzymatic and non-enzymatic antioxidant biomarkers include catalase (CAT), which reduces $\mathrm{H}_{2} \mathrm{O}_{2}$ to $\mathrm{H}_{2} \mathrm{O}$ and $\mathrm{O}_{2}$, and the tripeptide reduced glutathione (GSH), a non-enzymatic antioxidant chemical capable to prevent damage to different cellular constituents caused by ROS. GSH may act as a cofactor for ROS-detoxifying enzymes such as glutathione-dependent peroxidases or glutathione-Stransferases (GST). It is oxidized in the reaction that metabolizes $\mathrm{H}_{2} \mathrm{O}_{2}$ into $\mathrm{H}_{2} \mathrm{O}$ and thus it is converted to its oxidized form, glutathione disulphide. Once oxidized, it can be reduced back by GSH reductase, being the relation between GSH and oxidized glutathione, a useful parameter in the evaluation of oxidative stress (van der Oost et al. 2003). The GST catalyses the union of GSH to toxic compounds, increasing their solubility and facilitating their excretion.

Finally, another enzyme widely employed in studies of neurotoxicity is acetylcholinesterase (AChE), which catalyses the breakdown of acetylcholine in cholinergic synapses. It is known that some pesticides inhibit AChE causing over-stimulation of the post-synaptic membrane, mechanisms that could conclude in cellular death (Ferrari et al. 2007; Varó et al. 2008).

Cnesterodon decemmaculatus is an endemic fish member of the family Poeciliidae with an extensive distribution in the Neotropical region. This is a small ovoviviparous, microomnivorous, benthic-pelagic, dimorphic, and nonmigratory fish (maximum size, $\approx 25$ and $45 \mathrm{~mm}$ for $\widehat{\delta} \delta^{\lambda}$ and $q$ + $q$, respectively), with a life span of 2-4 years, and it is often the most abundant and sometimes the only species present in small watercourses (Menni et al. 1996; WHO 2009). Due to several intrinsic characteristics, such as its small size, wide range of tolerance, ability to adjust to laboratory conditions, in addition to the fact that it is a nonmigratory species frequently present in high densities, it is commonly employed in bioassays (Soloneski and Larramendy 2017 and references therein). Recently, it has been employed to analyse pollutantsinduced toxicity among aquatic vertebrates, including the following: herbicides such as glyphosate, DIC, and 2,4-D; insecticides such as pirimicarb and chlorpyrifos (Soloneski and Larramendy 2017 and references therein); as well as heavy metals such as chromium (Vera-Candioti et al. 2011), cadmium (Baudou et al. 2017; Mastrángelo and Ferrari 2013), and zinc (Gómez et al. 1998). The use of $C$. decemmaculatus in in situ studies is also well documented, mostly in relation with the salubrity of contaminated river waters (de la Torre et al. 2005; Menéndez-Helman et al. 2015; Ossana et al. 2016).

In previous studies, the alkaline comet assay revealed the induction of primary DNA damage in erythrocytes of C. decemmaculatus after exposure to the commercial herbicide formulations of $57.7 \%$ DIC-based Banvel ${ }^{\circledR}$ and $58.4 \%$ 2,4-D-based DMA ${ }^{\circledR}$ (Ruiz de Arcaute et al. 2014b, 2016). Despite these results, and to the best of our knowledge, oxidative stress exerted by these auxinic herbicides on C. decemmaculatus has not been analysed so far.

The aim of the present study was to assess oxidative damage in DIC- and 2,4-D-commercial formulationsexposed C. decemmaculatus fish through DNA damage and oxidative stress biomarkers. Whereas for the evaluation of oxidative DNA damage, the modified version of comet assay using the endonucleases Endo III and Fpg was performed; the CAT, GST, GSH, and AChE activities were employed to assess the engagement of the antioxidant response to these two xenobiotics. 


\section{Materials and methods}

\section{Chemicals and quality control}

Banvel $^{\circledR}\left(57.71 \%\right.$ DIC) and DMA ${ }^{\circledR}(58.4 \%$ 2,4-D) were provided by their manufacturers, Syngenta Agro S.A. (Buenos Aires, Argentina) and Dow AgroSciences Argentina S.A. (Buenos Aires, Argentina), respectively. Restriction enzymes were acquired from New England Biolabs ${ }^{\circledR}$ Inc. (Ipswich, MA). Hydrogen peroxide $\left(\mathrm{H}_{2} \mathrm{O}_{2}\right)$ was purchased from Merck KGaA (Darmstadt, Germany) and dimethyl sulfoxide as well as the rest of the reactives employed were obtained from Sigma Chemical Co. (St. Louis, MO). Concentration analyses of both auxinic herbicides in the test solutions were verified by QV Chem Laboratory (La Plata, Buenos Aires, Argentina). Concentrations assessed throughout the study represent the nominal concentrations of the analyte present within the formulations Banvel ${ }^{\circledR}$ and $\mathrm{DMA}^{\circledR}$.

\section{Test species}

C. decemmaculatus were collected from a stream near La Plata City (Buenos Aires Province, Argentina), in a nonanthropized area located in a biosphere reserve away from agricultural areas, and immediately transferred to the laboratory. Acclimatization was carried out in aquariums with dechlorinated tap water (temperature, $25.0 \pm 1{ }^{\circ} \mathrm{C} ; \mathrm{pH}, 7.5 \pm$ 0.1 ; dissolved oxygen, $6.4 \pm 0.3 \mathrm{mg} / \mathrm{L}$; conductivity, $994 \pm$ $8.5 \mu \mathrm{S} / \mathrm{cm}$; hardness, $142 \pm 21.5 \mathrm{mg} \mathrm{CaCO} / \mathrm{L}$ ) and artificial aeration for a minimum of 20 days to $16 / 8 \mathrm{~h}$ light/dark cycle. Fish were fed with commercial fish food (TetraFin ${ }^{\circledR}$, TetraWerke, Melle, Germany).

\section{Experimental design}

Specimens were exposed in vivo for 48 and $96 \mathrm{~h}$ to a concentration equivalent to $25 \%$ of the $\mathrm{LC}^{5} 0_{96 \mathrm{~h}}$ of each commercial formulation Banvel ${ }^{\circledR}$ and $\mathrm{DMA}^{\circledR}$. The $\mathrm{LC} 0_{96 \mathrm{~h}}$ for both herbicides were reported previously (Ruiz de Arcaute et al. 2014b, 2016). All experimental points were carried out employing ten individuals in a 1$\mathrm{L}$ glass aquarium and exposed for 48 and $96 \mathrm{~h}$ to a concentration of $410 \mathrm{mg} / \mathrm{L}$ DIC- or $252 \mathrm{mg} / \mathrm{L}$ 2,4-D-based commercial formulations Banvel ${ }^{\circledR}$ and DMA ${ }^{\circledR}$, respectively. During the experiments, herbicide solutions were renewed daily. No food supply was provided during the experiments. Negative control (dechlorinated tap water) was performed in simultaneous with DIC- and 2,4-D-exposed fish. After 48 and $96 \mathrm{~h}$ of treatment, fish were anaesthetized by immersion in ice water (Ackerman et al. 2005; Summerfelt and Smith 1990) and blood samples were obtained for the alkaline SCGE assay following recommendations previously reported (Ruiz de Arcaute et al. 2014b,
2016; Vera-Candioti et al. 2013). For positive control, after solidification of the agarose layers and before lysis, slides were treated with $50 \mu \mathrm{M} \mathrm{H}_{2} \mathrm{O}_{2}\left(4{ }^{\circ} \mathrm{C}, 5 \mathrm{~min}\right)$. Afterwards, fish were subsectioned, and the body midsections - from the operculum up to the cloaca-corresponding to the visceral tissues were stored in freezing conditions $\left(-80^{\circ} \mathrm{C}\right)$ for antioxidant biomarker determination (MenéndezHelman et al. 2012; Nunes et al. 2005; Varó et al. 2008). All experiments were performed in triplicate and ran simultaneously.

\section{Endonuclease-modified alkaline comet assay}

The alkaline endonuclease-modified comet assay was performed as reported elsewhere (Collins et al. 1996; Guilherme et al. 2012; Soloneski et al. 2017) with adjustments previously published for other small aquatic vertebrate species (Pérez-Iglesias et al. 2017). Following Collins (2004) and Pérez-Iglesias et al. (2017), slides were incubated at $37{ }^{\circ} \mathrm{C}$ during 45 or 30 min with $50 \mu \mathrm{L}$ of Endo III (0.5 U) or Fpg (0.13 U), respectively, immediately after the lysis period. After the endonuclease incubation period, samples were processed according to the standard comet assay method. In order to classified damage level, nucleoids were ranked into five categories $(0-\mathrm{I}$, undamaged nucleoids; II-IV, damaged nucleoids) following previous suggestions (Çavaş and Könen 2007). Results for each treatment group are expressed as the mean number of damaged nucleoids per 100 cells analysed. The genetic damage index (GDI) was estimated as suggested by Pitarque et al. (1999).

\section{Antioxidant biomarkers determination}

Body midsection tissues from each fish employed in the comet assay experiments were homogenized with a glass/teflon homogenizer on ice at $3000 \mathrm{rpm}$ and 20 strokes. The resulting homogenate was mixed in a 1:8 $w / v$ proportion with buffer $\left(0.1 \mathrm{M} \mathrm{NaH}_{2} \mathrm{PO}_{4}, 0.15 \mathrm{M} \mathrm{KCl}, 1 \mathrm{mM}\right.$ EDTA, $1 \mathrm{mM}$ DTT, and $10 \% v / v$ glycerol, $\mathrm{pH} 8$ ) in order to obtain a postmitochondrial supernatant (PMS). For samples committed to determination of AChE activity, PMS was prepared from a 1/ 20 tissue $w / v$ at $\mathrm{pH}$ 8.0. PMS final homogenate was centrifuged at $10,000 \times g\left(10 \mathrm{~min}, 4^{\circ} \mathrm{C}\right)$. The resulting supernatant was employed for biomarker measurements.

CAT (EC1.11.1.6) activity was measured spectrophotometrically at $240 \mathrm{~nm}$ for $60 \mathrm{~s}\left(25^{\circ} \mathrm{C}\right)$ according to the technique proposed by Baudhuin et al. (1964). Ten to $20 \mu \mathrm{L}$ of PMS were mixed with $0.05 \mathrm{M} \mathrm{NaH}_{2} \mathrm{PO}_{4}$ buffer ( $\mathrm{pH} 7.2$ ) and $17.8 \mathrm{mM} \mathrm{H}_{2} \mathrm{O}_{2}$ in a final volume of $1.5 \mathrm{~mL}$. Results were expressed as micromole $\mathrm{H}_{2} \mathrm{O}_{2}$ consumed per minute milligram protein. 
GST (EC2.5.1.18) activity was measured according to the method proposed by Habig et al. (1974) at $340 \mathrm{~nm}\left(25^{\circ} \mathrm{C}\right)$ during a period of $2 \mathrm{~min}$. In a final volume of $1.3 \mathrm{~mL}, 10 \mu \mathrm{L}$ PMS was mixed with $0.1 \mathrm{M} \mathrm{NaH}_{2} \mathrm{PO}_{4}$ buffer $(\mathrm{pH} 6.5)$, $10 \mathrm{mM}$ GSH, and $20 \mathrm{mM}$ 1-chloro-2,4-dinitrobenzene (CDNB). GST activity was expressed as micromole CDNB conjugate formed per minute milligram protein.

GSH content was determined following the methodology of Ellman (1959). PMS and 10\% trichloroacetic acid (TCA) were mixed in the same proportion and then centrifuged at $10,000 \times g$ for $10 \mathrm{~min}\left(4^{\circ} \mathrm{C}\right)$. GSH estimation was carried out using $100 \mu \mathrm{L}$ of the resulting supernatant and $1 \mathrm{~mL}$ DTNB. Results were obtained at $412 \mathrm{~nm}$ for $15 \mathrm{~min}\left(25^{\circ} \mathrm{C}\right)$ against a GSH standard curve. Results were express in terms of acid-soluble thiols (AST) as micromole of soluble thiols per gram of tissue.

AChE (E.C.3.1.1.7) determination was performed following the methodology described by Ellman et al. (1961) at $412 \mathrm{~nm}$ at $8 \mathrm{~s}$ intervals, during $2 \mathrm{~min}$. The mixture comprised $10 \mu \mathrm{L}$ homogenate, $3 \mathrm{~mL}$ of $0.1 \mathrm{M} \mathrm{K}_{2} \mathrm{HPO}_{4}$ buffer $(\mathrm{pH} 8)$, $100 \mu \mathrm{L}$ of 5,5-dithiobis (2-nitrobenzoic acid) solution $(10 \mathrm{mM}$ DTNB) and 10-25 $\mu \mathrm{L}$ substrate $(0.075 \mathrm{M}$ acetylthiocholine iodide). For enzyme measurements, the substrate acetylthiocholine iodide was employed with an extinction coefficient of $13.6 \mathrm{mM} / \mathrm{cm}$. Enzyme activity was expressed as nanomole of substrate hydrolysed per minute milligram protein.

Tissue protein $(\mathrm{Pr})$ content was determined as described by Lowry et al. (1951) employing bovine serum albumin as standard.

All measurements of enzymatic and non-enzymatic biomarkers were made on the basis of average percentage normalized values. Enzymatic activities were calculated in terms of protein content of the sample and expressed as mean values \pm standard error of the mean. All measurements were performed in triplicate for each sample.

\section{Statistical analysis}

For results of the modified comet assay analysis and antioxidant biomarkers, a one-way ANOVA with Dunnett's test was performed in order to compare the effects of the treatments and controls on each group (Zar 2010). ANOVA assumptions were corroborated with Barlett's test for homogeneity of variances and $\chi^{2}$ test for normality. Herbicide-induced OD for each antioxidant biomarker (respect buffer-enzyme) in the modified comet assay was compared with a $t$ test for the difference of means with equal variances (Zar 2010). A KruskalWallis test was employed in the cases that did not perform the assumptions of normality. The level of significance chosen was 0.05 , unless indicated otherwise.

\section{Results}

\section{Endonuclease-modified alkaline SCGE assay}

Concentration analyses revealed no significant variations $(P>$ 0.05 ) of the test solutions throughout the experiments (concentration range, $98 \pm 5 \%$ recovery).

Results from the modified comet assay in circulating blood cells of $C$. decemmaculatus exposed fish to $410 \mathrm{mg} / \mathrm{L} \mathrm{DIC} \mathrm{or}$ $252 \mathrm{mg} / \mathrm{L} \mathrm{2,4-D}$ are presented in Table 1 and the net OD is illustrated in Fig. 1. The capability of Endo III and Fpg to recognize oxidized DNA bases within our experimental protocol was achieved by incubating nucleoids with $50 \mu \mathrm{M} \mathrm{H}_{2} \mathrm{O}_{2}$ (positive control). $\mathrm{H}_{2} \mathrm{O}_{2}$-nucleoid incubation induced an enhancement in the frequency of damaged nucleoids, the GDI, and OD levels in enzyme buffer-treated cells exposed to Endo III and Fpg $(P<0.001)$ (Table 1; Fig. 1).

In individuals exposed to DIC herbicide formulation, GDI value was enhanced by 4.06 and 2.54 times over negative control values in experiments lasting 48 and $96 \mathrm{~h}$, respectively $(P<0.001$; Table 1). Such differences resulted from an increase in the frequency of all categories of damaged nucleoids (types II-IV) $(0.01>P<0.001)$ and a decrease in the frequency of undamaged nucleoids (types $0-$ I) $(P<0.001$; Table 1$)$. Post-treatment with Fpg induced an enhancement in GDI and in the net OD compared with enzyme buffer-treated cells in DIC-exposed fish during both $48 \mathrm{~h}(P<0.01)$ and $96 \mathrm{~h}(P$ $<0.05$ ) (Table 1; Fig. 1). Alterations in DNA damage in nucleoids from fish exposed to DIC during $48 \mathrm{~h}$ and post-treated with Fpg were related to an enhancement in the frequency of type II, III, and IV nucleoids $(0.05<P<0.01)$. Moreover, after $96 \mathrm{~h}$ of exposure, an enhancement of type III nucleoids was observed $(P<0.05)$ (Table 1$)$. Oppositely, and despite of the exposure time, the incubation with Endo III did not produce any significant variation in DNA damage, GDI, and, thus, in the net OD in cells from DIC-exposed individuals when compared to enzyme buffer-treated cells $(P>0.05)$ (Table 1; Fig. 1).

When the exposure with 2,4-D-herbicide formulation was assessed, the GDI value was enhanced 3.84- and 5.10-fold over negative control values in experiments lasting 48 and 96 h, respectively $(P<0.001$; Table 1$)$. Such differences resulted from an increase in the frequency of all categories of damaged nucleoids (types II-IV) $(0.01>P<0.001)$ and a decreased frequency of undamaged nucleoids (type $0-\mathrm{I}$ ) $(P<0.001$; Table 1). Post-treatment with Fpg induced a significant increase in both GDI as well as in the net OD compared with enzyme buffer-treated cells from 2,4-D-exposed fish during both 48 and $96 \mathrm{~h}(P<0.01)$ (Table 1; Fig. 1). Differences in DNA damage in 2,4-D-exposed fish posttreated with Fpg for either 48 and $96 \mathrm{~h}$ were due to an increased frequency of type II and IV nucleoids $(0.05<P<$ 0.001 ) (Table 1). On the other hand, despite the exposure time, 


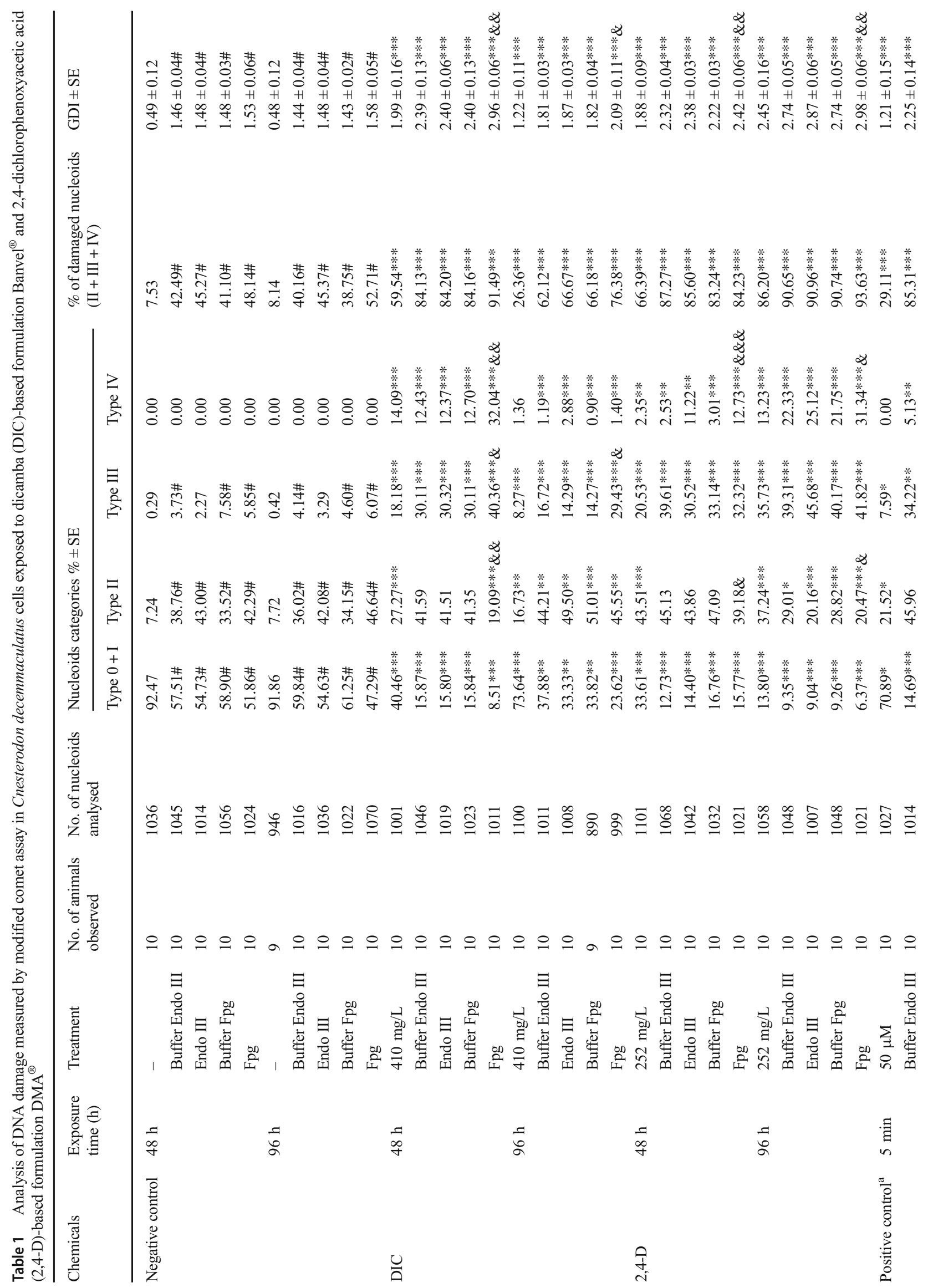


post-treatment with Endo III did not modify DNA damage, GDI, and net OD in cells from 2,4-D-exposed individuals in relation to enzyme buffer-treated cells (Table 1; Fig. 1).

\section{Antioxidant biomarkers determination}

The results of body midsection enzyme activities are presented in Table 2 . The mean values of CAT activity in control fish were $12.86 \pm 2.34$ and $13.52 \pm 2.96 \mu \mathrm{mol} \mathrm{H}_{2} \mathrm{O}_{2}$ hydrolysed/ min $\mathrm{mg}$ protein at 48 and $96 \mathrm{~h}$, respectively $(P>0.05)$. CAT activity was significantly increased in fish exposed either to DIC $(P<0.001)$ or $2,4-\mathrm{D}(0.01>P<0.001)$ commercial formulations exposed during 48 and $96 \mathrm{~h}$, respectively (Table 2).

Control GST activity was $0.04 \pm 0.01 \mu \mathrm{mol}$ CDNB conjugated form $/ \mathrm{min} \mathrm{mg}$ protein for both times of exposure $(P>0.05)$. In fish treated with both DIC- or 2,4-D-herbicide formulations, GST activity was enhanced when compared to control values either at $48 \mathrm{~h}(0.05>P<0.01)$ or $96 \mathrm{~h}$ of exposure $(P<0.001$; Table 2$)$.

Additionally, mean values of GSH activity in control fish were $3.17 \pm 0.56$ and $2.60 \pm 0.16 \mu \mathrm{mol} / \mathrm{g}$ ww at 48 and $96 \mathrm{~h}$, respectively $(P>0.05)$. In DIC-exposed fish, GSH concentration decreased after $48 \mathrm{~h}$ of exposure when compared to control values $(P<0.05)$. However, such a difference was not observed in $96 \mathrm{~h}$-exposed fish $(P>0.05)$. For 2,4-D-exposed organisms, an opposite scenario was observed. While no significant differences were found after $48 \mathrm{~h}$ of exposure $(P>0.05)$, a diminished GSH activity was detected in fish exposed over $96 \mathrm{~h}(P<0.01$; Table 2$)$.

Finally, control AChE activity was $384.71 \pm 17.33$ and $372.21 \pm 37.25 \mathrm{nmol}$ of substrate hydrolysed/min $\mathrm{mg}$ protein for both 48 and $96 \mathrm{~h}(P>0.05)$. A diminished AChE activity was observed in fish exposed either to DIC- or 2,4-D-based formulations during $96 \mathrm{~h}(P<0.01)$ but not in fish analysed after $48 \mathrm{~h}$ of exposure to both herbicides $(P>0.05$; Table 2$)$.

\section{Discussion}

In this investigation, oxidative stress in $C$. decemmaculatus when exposed to two commercial products containing the auxinic herbicides DIC and 2,4-D, Banvel ${ }^{\circledR}$ and $\mathrm{DMA}^{\circledR}$, respectively, was analysed using two widely employed bioassays such as endonuclease-modified alkaline comet assay and the activity of several antioxidant biomarkers.

Recently, results of the acute lethal and sublethal effects induced by DIC and 2,4-D employing C. decemmaculatus as test organism were reported (Ruiz de Arcaute et al. 2014b, 2016). In these studies, the alkaline comet assay demonstrated an increase of DNA damage in circulating blood cells of fish continuously exposed up to $96 \mathrm{~h}$ to DIC- and 2,4-D-based formulations Banvel ${ }^{\circledR}$ and $\mathrm{DMA}^{\circledR}$ within the 


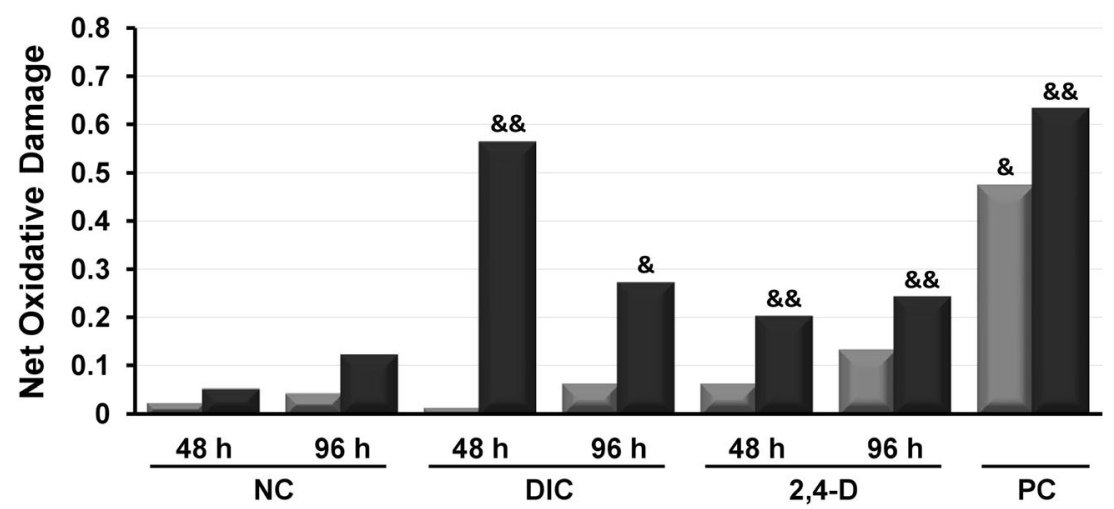

Fig. 1 DIC- and 2,4-D-based commercial formulations induced DNA damage evaluated by the Endo III (black bars)- and Fpg (grey bars)modified comet assay in circulating blood cells of Cnesterodon decemmaculatus. Net oxidative damage was expressed as the

410-1229 and 252-756 mg/L concentration ranges, respectively. It was also observed that such an effect was independent of the extent of the herbicide exposure period (Ruiz de Arcaute et al. 2014b, 2016). Besides, in these studies, the estimation of mortality, behavioural alterations, and the MN count were assayed as lethal and other sublethal biomarkers, respectively (Ruiz de Arcaute et al. 2014b, 2016).

Several xenobiotics, such as herbicides, can alter ROS balance via various mechanisms, such as alterations in enzymatic and non-enzymatic antioxidant defences, membrane lipid peroxidation, among others, providing a mechanistic basis for their observed toxicity (Kaya and Yigit 2012). The over production of ROS can eventually overcome the antioxidant capacity of the cells, a situation that leads to oxidative stress and depletion of antioxidant defence (Lushchak 2011; Muthulakshmi et al. 2018), causing irreversible damage in cellular macromolecules and affecting cellular function and viability (Costantini and Verhulst 2009; Poletta et al. 2016). Lipid damage affects a cell's membrane structure, making subtraction between the score obtained after incubation with the respective enzyme or with the buffer. Hydrogen peroxide $(50 \mu \mathrm{m})$ was employed as a positive control. \& $P<0.05$; \&\&, $P<0.01$; significant differences with the respective buffer-enzyme

them less permeable and jeopardizing their integrity, and protein oxidation alters their conformation and could, depending on their location and structure, compromise their function (Hulbert et al. 2007; Poletta et al. 2016). Ultimately, this situation could lead, then, to tissue, cellular, and DNA damage as well (Hulbert et al. 2007).

It is believed that DIC and 2,4-D could mediate jeopardizing effects on organisms associated with ROS generation (Espandiari et al. 1998; Peixoto et al. 2008). For the auxinic herbicide 2,4-D, evidence of its contribution in the production of ROS has been reported (Bukowska 2003, 2006; Oruç and Üner 2000; Romero-Puertas et al. 2004). Specifically for fish, oxidative stress has been shown, e.g. in the goldfish Carassius auratus (Atamaniuk et al. 2013; Kubrak et al. 2013; Matviishyn et al. 2014), the zebrafish Danio rerio (Li et al. 2017), the European carp Cyprinus carpio (Oruç et al. 2004), and the Nile tilapia Oreochromis niloticus (Oruç et al. 2004). As far as we know, there is no information regarding oxidative stress induced by DIC on fish species.

Table 2 Analysis of biomarkers in Cnesterodon decemmaculatus cells exposed to dicamba (DIC)-based formulation Banvel ${ }^{\circledR}$ and 2,4dichlorophenoxyacetic acid (2,4-D)-based formulation DMA ${ }^{\circledR}$

\begin{tabular}{|c|c|c|c|c|c|c|}
\hline \multirow[t]{2}{*}{ Chemicals } & \multirow[t]{2}{*}{ Exposure time (h) } & \multicolumn{5}{|c|}{ Biomarkers $(\text { mean } \pm \mathrm{SE})^{\mathrm{a}}$} \\
\hline & & $\operatorname{Pr}$ & CAT & GST & GSH & $\mathrm{AChE}$ \\
\hline Negative control & 48 & $106.82 \pm 13.18$ & $12.86 \pm 2.34$ & $0.04 \pm 0.01$ & $3.17 \pm 0.56$ & $384.71 \pm 17.33$ \\
\hline DIC & & $98.22 \pm 7.78$ & $51.59 \pm 6.40 * * *$ & $0.09 \pm 0.01 * *$ & $1.56 \pm 0.15^{*}$ & $343.87 \pm 89.81$ \\
\hline $2,4-\mathrm{D}$ & & $80.30 \pm 8.45$ & $68.91 \pm 20.27 * * *$ & $0.07 \pm 0.01^{*}$ & $2.08 \pm 0.13$ & $267.11 \pm 45.79$ \\
\hline Negative control & 96 & $115.58 \pm 16.18$ & $13.52 \pm 2.96$ & $0.04 \pm 0.01$ & $2.60 \pm 0.16$ & $372.21 \pm 37.25$ \\
\hline DIC & & $81.02 \pm 7.85^{*}$ & $30.08 \pm 3.82 * * *$ & $0.07 \pm 0.01 * * *$ & $2.06 \pm 0.25$ & $217.48 \pm 65.07 * *$ \\
\hline $2,4-\mathrm{D}$ & & $57.18 \pm 4.81 * * *$ & $41.55 \pm 6.57 * * *$ & $0.10 \pm 0.01 * * *$ & $1.04 \pm 0.03 * *$ & $164.24 \pm 34.54 * *$ \\
\hline
\end{tabular}

GST glutathione-S-transferase as micromole CDNB conjugated formed per minute milligram protein, GSH glutathione content as soluble acid thiols micromole per gram ww, $A C h E$ nanomole of substrate hydrolysed per minute milligram protein

$* P<0.05 ; * * P<0.01 ; * * * P<0.001$, significant differences with the control group

${ }^{a}$ Biomarkers: Pr, protein content as milligram per gram ww; CAT, catalase as micromole $\mathrm{H}_{2} \mathrm{O}_{2}$ consumed per minute milligram protein 
To elucidate the potential type of lesions that DIC and 2,4D induce into the DNA of the auxinic herbicide-exposed specimens of $C$. decemmaculatus, we employed the modified comet assay, in which a digestion with lesion-specific endonucleases was included. Our current observations reveal that post-treatment with enzyme buffer enhances, by itself, the level of DNA damage. It is known that the enzyme buffer of Fpg and EndoIII is able to induce DNA damage, by a mechanism still unknown. So far, at least two of the components contained within the enzyme buffer formulation, i.e. ethylenediaminetetraacetic acid (EDTA) and 2-[4-(2-hydroxyethyl)-1piperazinyl] ethanesulfonic acid (HEPES), have been previously informed to induced DNA damage. Ye et al. (2012) report that EDTA induced not only DNA damage evaluated by alkaline comet assay but also a dose-related increase in ROS levels in human corneal epithelial cells cultures. Furthermore, Heindorff et al. (1983) reviewed the genetic toxicology of EDTA reporting its ability to induce chromosomal damage in plants, animals, and human leucocyte cultures. Finally, Habib and Tabata (2004) found that HEPES in the presence of $\mathrm{Au}(\mathrm{III})$ induce oxidative damage when evaluated by gel electrophoresis, electron spin resonance spectroscopy, and circular dichroism spectroscopy. Our current results agree well with previous observations stressing the capability of the buffer to introduce damage into the nucleoid DNAs, and thus, increasing their length (Collins and Azqueta 2012; Demir et al. 2014; Pérez-Iglesias et al. 2017; Soloneski et al. 2016; Soloneski et al. 2017).

Our results prove the efficacy of Fpg, in combination with the comet assay for detecting damaged purines in the DNA of circulating blood cells of $C$. decemmaculatus treated with the auxinic herbicides DIC and 2,4-D in their commercial formulations Banvel ${ }^{\circledR}$ and $\mathrm{DMA}^{\circledR}$, respectively. On the other hand, post-treatment with Endo III did not increase Banvel ${ }^{\circledR}$ - or $\mathrm{DMA}^{\circledR}$-induced damage, indicating that these auxinic formulations do not induce damage through oxidative damage at pyrimidine level. Fpg recognizes the common oxidized purine 8-oxoGua, and also ring-opened purines, or formamidopyrimidines (Fapy). Finally, we cannot discard the possibility that the high level of damage we detected with Fpg may be over estimated due to the presence of formamidopyrimidines in addition to 8-oxoGua.

Positive results have also been reported when employing the Fpg-modified comet assay in the European eel (Anguilla anguilla) treated with glyphosate present in the formulation Roundup ${ }^{\circledR}$ (Guilherme et al. 2012) or in the in common bleak (Alburnus alburnus) when used as biotic matrix to evaluate the environmental risk of the water contamination of the Velika Morava River basin (Jovanović et al. 2018). So far, the Fpg-modified comet assay was only used by Lajmanovich et al. (2015) in mature erythrocytes of the common American toad Rhinella arenarum exposed to 2,4-D to assess to ability of the glycosylase to transform oxidized purines into DNA single-strand breaks. However, no induction of DNA damage was revealed by the comet assay or by the Fpg-modified version when the 2,4-D-based commercial formulation Asi Max $50^{\circledR}(50 \%$ 2,4-D) was employed in this anuran species (Lajmanovich et al. 2015). So far, we do not possess a clear answer to explain the contradictory results obtained in the common toad R. arenarum in regard to our current observations. However, although speculative, it could be suggested that they might most probably be related to the employed dose of 2,4-D since negative results were reported after employing a dose nearly 12 times lower than that employed in our experimental design (Lajmanovich et al. 2015). As far as we know, no studies employing the Fpgand Endo III-modified alkaline SCGE assay on DIC- and 2,4-D-exposed fish have been reported so far. Thus, our study demonstrates for the first time DNA oxidative damage induced after exposure to a pollutant employing the glycosylase-modified SCGE assay in an aquatic organism like C. decemmaculatus.

In the present study, increased activities of the enzymes CAT and GST were observed in fish exposed for 48 and $96 \mathrm{~h}$ to both DIC and 2,4-D. In agreement to our observations, an enhancement in CAT activity has been previously reported in fish exposed to several herbicides. Among them, higher CAT levels in regard to non-exposed organisms have been reported in the zebra fish $D$. rerio after treatment with bipyridylium herbicide diquat (Wang et al. 2018), the threebarbeled catfish Rhamdia quelen (Persch et al. 2017) and the characin Leporinus obtusidens (Glusczak et al. 2011) exposed to the glyphosate-based formulation Roundup ${ }^{\circledR}$ as well as in the climbing perch Anabas testudineus and the stinging catfish Heteropneustes fossilis as a consequence of a glyphosatebased formulation Excel Mera 71 exposure (Samanta et al. 2014). Similar observations were also reported for the streaked prochilod Prochilodus lineatus exposed to atrazine (Paulino et al. 2012) and for the common carp C. carpio after simazine treatment (Stara et al. 2012).

As observed for CAT, GST activity was also increased after 48 and $96 \mathrm{~h}$ treatment with DIC- and 2,4-D-herbicide formulations. An increased activity of GST could expose disorders related to an oxidative stress situation, as has been previously confirmed in the Nile tilapia $O$. niloticus and the common carp C.carpio exposed to a formulated product containing 2,4-D (trade name not specified), to the azinphosmethyl-based formulation Guthion 20 EC (Oruç et al. 2004; Oruç and Üner 2002), and to the triazine compounds terbuthylazine and metribuzin (Hostovsky et al. 2012). Besides, and in agreement with our observations, similar raised GST activity has also reportedly occurred, among others, in the hybrid fish jundiara Leiarius marmoratus $\times$ Pseudoplatystoma reticulatum exposed to the glyphosate-based formulation Roundup Original ${ }^{\circledR}$ (de Moura et al. 2017) as well as in the streaked prochilod P. lineatus exposed to atrazine (Paulino et al. 2012). 
Therefore, it could be assumed that the increased CAT and GST activity could help to prevent oxidative damage caused in the specimens of $C$. decemmaculatus exposed to both auxinic herbicides.

Additionally, to the aforementioned altered markers for oxidative stress, a decrease of GSH was registered in specimens treated for 48 and $96 \mathrm{~h}$ with either DIC- or 2,4-D-herbicide formulations. GSH is part of the first defence of organisms against oxidative stress (Finkel and Holbrook 2000). Xenobiotics that make contact with the cells are removed by conjugation with GSH or by means of GST, a process that decreases GSH levels (Elia et al. 2003). In agreement to our results, a similar diminished GSH activity has been reported after exposure to other herbicides in different fish species such as the Delta smelt Hypomesus transpacificus exposed to the fluridone-based formulation Sonar ${ }^{\circledR}$ AS and to the glyphosate-based formulated product Roundup ${ }^{\circledR}$ Custom (Jin et al. 2018) as well as the rainbow trout Oncorhynchus mykiss exposed to commercial linuron (formulation not specified) (Topal et al. 2017), among others. The diminished GSH activity reported in our results could be due to either a high intracellular demand of GSH associated with the endobiotic detoxification processes of DIC and 2,4-D or by an increased production of ROS exerted by the herbicides raising the general oxidative potential required for these processes (Mela et al. 2013; Pamela and Richard 1994). Previous investigations have reported that GSH conjugates with environmental contaminants either by a spontaneous manner or catalysed by GST enzyme detoxification (Elia et al. 2003). Our results agree with the pattern reported previously by Elia et al. (2003) in the black bullhead catfish Ameiurus melas as a consequence of mercury exposure. Authors observed an enhanced GST level and a concomitant decrease in the GSH content, a similar situation to what we found in C. decemmaculatus after both auxinic herbicide treatments reported in the current study.

Considering the diminished activity of AChE in auxinic herbicide-exposed fish we observed, enzyme inhibition could be proposed as a possible mechanism through which DIC- and 2,4-D-herbicide formulations could induce oxidative stress. Although speculative, a plausible explanation for these findings could be suggested. The inhibition of AChE leads to an over stimulation of an organism's nervous system, pointing out, thus, the potential neurotoxic effects of the auxinic herbicides employed in this study as anticholinergic compounds. Several investigations confirmed that $\mathrm{AChE}$ is a sensitive parameter for neurotoxicity exerted by other xenobiotics such as pyrethroids and herbicides rather than that very well-known neurotoxic agents such as carbamates and organophosphorus pesticides (Kumar et al. 2009). Extending this concept, it has been reported a dose-dependent decrease in the levels of $\mathrm{AChE}$ in the spotted snakehead Channa punctatus exposed to the insecticides $\lambda$-cyhalothrin-based formulation Colt ${ }^{\circledR} 25$ as well as to the cypermethrin-based formulation REEVA-5, the former being more potent than the latter (Kumar et al. 2009). Specifically, similar results have been found after exposure of the characin L. obtusidens exposed to the herbicide glyphosate-based formulation Roundup ${ }^{\circledR}$ (Glusczak et al. 2011; Salbego et al. 2010) and the Delta smelt Hypomesus transpacificus exposed to the fluridone-based formulation Sonar ${ }^{\circledR}$ AS, to the penoxsulam-based formulated product Galleon ${ }^{\circledR}$ SC, or to Clearcast ${ }^{\circledR}$, an imazamox-based herbicide formulation (Jin et al. 2018). In fish, AChE activity is important in motion capacity, predation, and social interactions (Rodríguez-Fuentes et al. 2015). In addition, AChE alteration could alter early development as informed by Behra et al. (2002). In agreement, we have previously observed the appearance of behavioural changes in $C$. decemmaculatus specimens after auxinic herbicide exposure to sublethal concentrations (Ruiz de Arcaute et al. 2014b, 2016).

Diminished protein content was detected in exposed specimens, indicating that the auxinic herbicides employed caused alterations in the protein metabolism of exposed C. decemmaculatus. The pesticide-induced inhibitory effect on protein level is a very well-documented aspect in toxicological studies when fish are employed as a biotic matrix (Lal et al. 2013; Naqvi et al. 2017; Samanta et al. 2014). Our results agree with several observations previously reported on several fish species exposed to a wide variety of different active ingredients of pesticides, including insecticides, e.g. fenvalerate (Tripathi and Verma 2004b), chlorpyrifos (Naqvi et al. 2017), malathion (Lal et al. 2013; Naqvi et al. 2017), $\alpha$-cypermethrin (Tripathi and Singh 2013), cypermethrin (Kumar et al. 2009; Naqvi et al. 2017; Ullah et al. 2014), $\lambda$-cyhalothrin (Kumar et al. 2009; Naqvi et al. 2017), permethrin (Sapana Devi and Gupta 2014), б-methrin (Sapana Devi and Gupta 2014), fenitrothion (Katsiadaki et al. 2006; Sancho et al. 1997), diazinon (Ozcan Oruç et al. 2006), endosulfan (Tripathi and Verma 2004a), and herbicides, e.g. atrazine (Persch et al. 2017), linuron (Katsiadaki et al. 2006), benthiocarb (Rao et al. 1987; Seshagiri et al. 1987), glyphosate (Glusczak et al. 2011; Persch et al. 2017; Samanta et al. 2014), quinclorac (Persch et al. 2017), among others. It is worth mentioning that similar results on total protein content were observed recently in the Mozambique tilapia O. mossambicus after exposure to several commercially available products (formulations not specified) based on organophosphate and synthetic pyrethroid insecticides and herbicides (Naqvi et al. 2017). These authors proposed several alternatives to explain the diminution of protein content. Among them, a physiological response of the organism to compensate xenobiotic-induced stress, an enhanced proteolytic activity or reduced protein synthesis, hormonal imbalances affecting normal tissue protein levels, cellular necrosis, and/or altered enzymatic activities due to DNA damage (Naqvi et al. 2017). So far, we do not possess clear evidence allowing us to accept or reject any of the 
aforementioned plausible explanations. However, our current results clearly highlight that inhibition of protein increased in both DIC- and 2,4-D-exposed fish during $96 \mathrm{~h}$ as compared to $48 \mathrm{~h}$ and that a stronger effect was achieved in 2,4-D-exposed C. decemmaculatus than that exerted by DIC.

It is worth mentioning that in the present study, a DICbased herbicide containing $57.7 \%$ of the active ingredient within the formulation Banvel ${ }^{\circledR}$ as well as a 2,4-D-based herbicide containing $58.4 \%$ of the active ingredient within the formulation DMA ${ }^{\circledR}$ were assayed. It is known that in a pesticide formulated product, the active ingredient is combined with organic solvents, emulsifying and wetting agents to achieve an optimal penetration and performance (WHO 2009). Although additive compounds involve part of a commercial pesticide formulation, they are not usually included in the discussion of the effects on living non-target organisms, and their adverse effects can go beyond those of the active principle. In agreement, several authors agree and have demonstrated that the excipients present in pesticide commercial products are able to induce both toxicity and cellular damage by themselves rather than the pure compound either in vitro or in vivo (Mann and Bidwell 1999; Mansano et al. 2016a, 2016b; Molinari et al. 2013; Nikoloff et al. 2014; PérezIglesias et al. 2014; Ruiz de Arcaute et al. 2014a; Soloneski and Larramendy 2010). Regrettably, the identities of the additive compounds present in the formulations Banvel ${ }^{\circledR}$ and $\mathrm{DMA}^{\circledR}$ were not made available to us by the manufacturers. According to the Argentinean administration, excipients present in any agrochemical are not obligatory for listing on agrochemical data sheets and can be kept as a "trade secret." Further studies should be required to reveal whether the sublethal damage exerted by these auxinic formulations results from the presence of xenobiotic(s) with oxidative damage properties included in the formulated products.

The physico-chemical properties of DIC and 2,4-D make these herbicides highly mobile in soil and thereby often present in the aquatic environment (Glozier et al. 2012; Li et al. 2009). Previous observations indicate that these auxinics have been detected in urban and peri-urban sites as well as in agroecosystems (Félix-Cañedo et al. 2013; Glozier et al. 2012; Loos et al. 2010; Tagert et al. 2014). Environmental concentrations of these auxinic herbicides have been reported in countries such as USA, Canada, and Mexico in ranges from 0.04 up to $24 \mu \mathrm{g} / \mathrm{L}$. In Argentina, only one study reports a 2,4D concentration of $0.99 \mu \mathrm{g} / \mathrm{L}$ found in El Crespo River in Buenos Aires Province. As far as we know, there is no information available on the environmental concentrations of DIC in Argentina. Although treatments in this study comprise one concentration of DIC $(410 \mathrm{mg} / \mathrm{L})$ and 2,4-D $(252 \mathrm{mg} / \mathrm{L})$, they represent a relatively high end of the threshold values found in the environment of both herbicides and reported so far. Thus, it could be assumed that the concentrations of the auxinic herbicides assayed in the present study would be almost improbable to be found in the biosphere, possibly only after specific incidents, such as direct application, accidental discharge, and treatment of application residues, among others. Due to the aforementioned situations, we cannot discard the possibility that piscine populations of $C$. decemmaculatus, as well as others living species, could be exposed to the auxinic herbicides employed at these concentrations.

The present findings demonstrate that both auxinics DIC and 2,4-D in their formulated products Banvel ${ }^{\circledR}$ and $\mathrm{DMA}^{\circledR}$, respectively, act as oxidizing agents on non-target species such as the Neotropical fish $C$. decemmaculatus. Furthermore, our results emphasize that the biomarkers assayed are valuable for evaluating contaminated aquatic environments, at least when employing the fish $C$. decemmaculatus.

Acknowledgments The authors thank Syngenta Agro S.A. (Buenos Aires, Argentina) and Dow AgroSciences Argentina S.A. (Buenos Aires, Argentina) for kindly providing the formulations Banvel ${ }^{\mathbb{R}}$ and $\mathrm{DMA}^{\circledR}$, respectively.

Funding information The experiments performed in the present study were supported by grants from the National University of La Plata (Grants 11/N817 and 11/N847) and the National Agency of Scientific and Technological Promotion (PICT 2015 Number 3059) from Argentina.

\section{Compliance with ethical standards}

Conflict of interest The authors declare that there are no conflicts of interest.

\section{References}

Ackerman PA, Morgan JD, Iwama GK (2005) Anestethics. In: CCoA C (ed) The care and use of fish in research, teaching and testing. Canadian Council on Animal Care, Ottawa, CA, pp 1-22

Adhikari N, Graver IS (1988) Genotoxic effects of some systemic pesticides: in vivo chromosomal aberrations in bone marrow cells in rats. Environ Mol Mutagen 12:235-242

Amer SM, Aly FAE (2001) Genotoxic effect of 2,4-dichlorophenoxy acetic acid and its metabolite 2,4-dichlorophenol in mouse. Mutat Res 494:1-12

Arias E (2007) Cytogenetic effects of short- and long-term exposure of chick embryos to the phenoxyherbicide 2,4-D. Environ Mol Mutagen 48:462-466

Atamaniuk TM, Kubrak OI, Storey KB, Lushchak VI (2013) Oxidative stress as a mechanism for toxicity of 2,4-dichlorophenoxyacetic acid (2,4-D) studies with goldfish gills. Ecotoxicology 22:1498-1508

Ateeq B, Farah MA, Ali MN, Ahmad W (2002) Clastogenicity of pentachlorophenol, 2,4-D and butachlor evaluated by Allium root tip test. Mutat Res 514:105-113

Ateeq B, Farah MA, Ahmad W (2005) Detection of DNA damage by alkaline single cell gell electrophoresis in 2,4-dichlorophenoxyacetic-acidand butachlor-exposed erythrocytes of Clarias batrachus. Ecotoxicol Environ Saf 62:348-354

Azqueta A, Campos Costa-Amaral I, Collins AR (2017) High-throughput measurements of DNA breaks and oxidised bases with the comet assay. In: Dhawan A, Anderson D (eds) The comet assay in toxicology. The Royal Society of Chemistry, Cambridge, UK, pp 67-87 
Baudhuin P, Beaufay H, Rahman-Li Y, Sellinger OZ, Wattiaux R, Jacques $\mathrm{P}$, al. e (1964) Tissue fractionation studies. 17. Intracellular distribution of monoamine oxidase, alanine aminotransferase, D-amino acid oxidase and catalase in rat liver tissue. Biochem J 91:179-184

Baudou FG, Ossana NA, Castañé PM, Mastrángelo MM, Ferrari L (2017) Cadmium effects on some energy metabolism variables in Cnesterodon decemmaculatus. Ecotoxicology 26:1250-1258

Behra M, Cousin X, Bertrand C, Vonesch JL, Biellmann D, Chatonnet A, Strähle U (2002) Acetylcholinesterase is required for neuronal and muscular development in the zebrafish embryo. Nat Neurosci 5: $111-118$

Bokán K, Syberg K, Jensen K, Rank J (2013) Genotoxic potential of two herbicides and their active ingredients assessed with comet assay on a fish cell line, Epithelioma Papillosum Cyprini (EPC). J Toxicol Environ Health 76:1129-1137

Bony S, Gaillard I, Devaux A (2010) Genotoxicity assessment of two vineyard pesticides in zebrafish. Int J Environ Anal Chem 90:421428

Bukowska B (2003) Effects of 2,4-D and its metabolite 2,4-dichlorophenol on antioxidant enzymes and level of glutathione in human erythrocytes. Comp Biochem Physiol C 135:435-441

Bukowska B (2006) Toxicity of 2,4-dichlorophenoxyacetic acidmolecular mechanisms. Pol J Environ Stud 15:365-374

Cadet J, Douki T, Gasparutto D, Ravanat JL (2003) Oxidative damage to DNA: formation, measurement and biochemical features. Mutat Res 531:5-23

CASAFE (2017) Guía de Productos Fitosanitarios para la República Argentina. Cámara de Sanidad Agropecuaria y Fertilizantes, 1200 pp

Cavalcante DG, Martinez CB, Sofia SH (2008) Genotoxic effects of Roundup on the fish Prochilodus lineatus. Mutat Res 655:41-46

Çavaş T, Könen S (2007) Detection of cytogenetic and DNA damage in peripheral erythrocytes of goldfish (Carassius auratus) exposed to a glyphosate formulation using the micronucleus test and the comet assay. Mutagenesis 22:263-268

Collins AR (2004) The comet assay for DNA damage and repair: principles, applications, and limitations. Mol Biotechnol 26:249-261

Collins AR, Azqueta A (2012) DNA repair is a biomarker in human biomonitoring studies; further applications of the comet assay. Mutat Res 736:122-129

Collins AR, Dusinská M, Gedik CM, Stetina R (1996) Oxidative damage to DNA: do we have a reliable biomarker? Environ Health Perspect 104:465-469

Cooke MS, Olinski R, Evans MD (2006) Does measurement of oxidative damage to DNA have clinical significance? Clin Chim Acta 365: $30-49$

Costantini D, Verhulst S (2009) Does high antioxidant capacity indicate low oxidative stress? Funct Ecol 23:506-509

de la Torre FR, Ferrari L, Salibián A (2005) Biomarkers of a native fish species (Cnesterodon decemmaculatus) application to the water toxicity assessment of a peri-urban polluted river of Argentina. Chemosphere 59:577-583

de Moura FR, Brentegani KR, Gemelli A, Sinhorin AP, Sinhorin VDG (2017) Oxidative stress in the hybrid fish jundiara (Leiarius marmoratus $\mathrm{x}$ Pseudoplatystoma reticulatum) exposed to Roundup Original ${ }^{\circledR}$. Chemosphere 185:445-451

Demir E, Akça H, Kaya B, Burgucu D, Tokgün O, Turna F, Aksakal S, Vales G, Creus A, Marcos R (2014) Zinc oxide nanoparticles: genotoxicity, interactions with UV-light and cell-transforming potential. J Hazard Mater 264:420-429

Dhawan A, Anderson D (eds) (2017) The comet assay in toxicology. Issues in toxicology. The Royal Society of Chemistry, Cambridge, $\mathrm{UK}, 590 \mathrm{pp}$

Elia AC, Galarini R, Taticchi MI, Dörr AJM, Mantilacci L (2003) Antioxidant responses and bioaccumulation in Ictalurus melas under mercury exposure. Ecotoxicol Environ Saf 55:162-167
Ellman GL (1959) Tissue sulfhydryl groups. Arch Biochem Biophys 82: 70-77

Ellman GL, Courtney KD, Andreas VJ, Feathersone RM (1961) A new and rapid colorimetric determination of acetylcholinesterase activity. Biochem Pharmacol 7:88-95

Espandiari P, Ludewig G, Glauert HP, Robertson LW (1998) Activation of hepatic NF- $\mathrm{KB}$ by the herbicide dicamba (2-methoxy-3,6dichlorobenzoic acid) in female and male rats. J Biochem Mol Toxicol 12:339-344

Farah MA, Ateeq B, Ahmad W (2006) Antimutagenic effect of neem leaves extract in freshwater fish, Channa punctatus evaluated by cytogenic tests. Sci Total Environ 364:200-214

Félix-Cañedo TE, Durán-Álvarez JC, Jiménez-Cisneros B (2013) The ocurrence and distribution of a group of organic micropollutants in Mexico City's water sources. Sci Total Environ 454-455:109-118

Ferrari A, Venturino A, Pechén de D'angelo M (2007) Muscular and brain cholinesterase sensitivities to azinphos methyl and carbaryl in the juvenile rainbow trout Oncorhynchus mykiss. Comp Biochem Physiol C Toxicol Pharmacol 146:308-313

Finkel TH, Holbrook NJ (2000) Oxidants, oxidative stress and the biology of aging. Nature 408:239-247

Glozier NE, Struger J, Cessna AJ, Gledhill M, Roundeau M, Ernst WR, Sekela MA, Cagampan SJ, Sverko E, Murphy C, Murray JL, Donald DB (2012) Occurrence of glyphosate and acidic herbicides in select urban rivers and streams in Canada, 2007. Environ Sci Pollut Res 19:821-834

Glusczak L, Loro VL, Pretto A, Moraes BS, Raabe A, Duarte MF, da Fonseca MB, de Menezes CC, de Sousa Valladao DM (2011) Acute exposure to glyphosate herbicide affects oxidative parameters in piava (Leporinus obtusidens). Arch Environ Contam Toxicol 61: 624-630

Gómez S, Villar C, Bonetto C (1998) Zinc toxicity in the fish Cnesterodon decemmaculatus in the Parana river and Rio de la Plata estuary. Environ Pollut 99:159-165

González M, Soloneski S, Reigosa MA, Larramendy ML (2005) Genotoxiciy of the herbicide 2,4-dichlorophenoxyacetic acid and a commercial formulation, 2,4-dichlorophenoxyacetid acid dimethylamine salt. I. Evaluation of DNA damage and cytogenetic endopoints in Chinese hamster ovary $(\mathrm{CHO})$ cells. Toxicol in Vitro 19:289-297

González N, Soloneski S, Larramendy ML (2006) Genotoxicity analysis of the phenoxy herbicide dicamba in mammalian cells in vitro. Toxicol in Vitro 20:1481-1487

González N, Soloneski S, Larramendy ML (2007) The chlorophenoxy herbicide dicamba and its commercial formulation banvel induce genotoxicity in Chinese hamster ovary cells. Mutat Res 634:60-68

González N, Soloneski S, Larramendy ML (2011) A combination of the cytokinesis-block micronucleus cytome assay and centromeric identification for evaluation of the genotoxicity of dicamba. Toxicol Lett 207:204-212

Guilherme S, Santos MA, Barroso C, Gaivão I, Pacheco M (2012) Differential genotoxicity of RoundUp® formulation and its constituents in blood cells of fish (Anguilla anguilla) considerations on chemical interactions and DNA damaging mechanisms. Ecotoxicology 21:1381-1390

Habib A, Tabata M (2004) Oxidative DNA damage induced by HEPES (2-[4-(2-hydroxyethyl)-1-piperazinyl]ethanesulfonic acid) buffer in the presence of Au(III). J Inorg Biochem 98:1696-1702

Habig WH, Pabst MJ, Jakoby WB (1974) Glutathione S-transferases. The first enzimatic step in mercapturic acid formation. J Biol Chem 22: 7130-7139

Heindorff K, Aurich O, Michaelis A, Rieger R (1983) Genetic toxicology of ethylenediaminetetraacetic acid. Mutat Res 115:149-173

Hostovsky M, Blahova J, Plhalova L, Stepanova S, Praskova E, Marsalek P, Svobodova Z (2012) Oxidative stress parameters in early developmental stages of common carp (Cyprinus carpio L.) after 
subchronic exposure to terbuthylazine and metribuzin. Neuro Endocrinol Lett 33:124-129

Hulbert AJ, Pamplona R, Buffenstein R, Buttemer WA (2007) Life and death: metabolic rate, membrane composition, and life span of animals. Physiol Rev 87:1175-1213

Jin J, Kurobe T, Ramírez-Duarte WF, Bolotaolo MB, Lam CH, Pandey PK, Hung T-C, Stillway ME, Zweig L, Caudill J, Lin L, Teh SJ (2018) Sub-lethal effects of herbicides penoxsulam, imazamox, fluridone and glyphosate on Delta smelt (Hypomesus transpacificus). Aquat Toxicol 197:79-88

Jovanović J, Kolarević S, Milošković A, Radojković N, Simić V, Dojčinović B, Kračun-Kolarević M, Paunović M, Kostić J, Sunjog K, Timilijić J, Djordjević J, Gačić Z, Žegura B, Vuković-Gačić B (2018) Evaluation of genotoxic potential in the Velika Morava River basin in vitro and in situ. Environ Sci Pollut Res 621:1289-1299

Katsiadaki I, Morris S, Squires C, Hurst MR, James JD, Scott AP (2006) Use of the three-spined stickleback (Gasterosteus aculeatus) as a sensitive in vivo test for detection of environmental antiandrogens. Environ Health Perspect 114:115-121

Kaya A, Yigit E (2012) Interactions among glutathione S-transferase, glutathione reductase activity and glutathione contents in leaves of Vicia faba L. subjected to flurochloridone. Fresenius Environ Bull 21:1635-1640

Kubrak OI, Atamaniuk TM, Husak VV, Lushchak VI (2013) Transient effects of 2,4-dichlorophenoxyacetic acid (2,4-D) exposure on some metabolic and free radical processes in goldfish white muscle. Food Chem Toxicol 59:356-361

Kumar A, Rai DA, Sharma B, Pandey RS (2009) $\lambda$-Cyhalothrin and cypermethrin induced in vivo alterations in the activity of acetylcholinesterase in a fresh-water fish, Channa punctatus (Bloch). Pesticide Biochem Physiol 93:96-99

Lajmanovich RC, Attademo AM, Simoniello MF, Poletta GL, Junges CM, Peltzer PM, Grenón P, Cabagna-Zenklusen MC (2015) Harmful effects of the dermal intake of commercial formulations containing chlorpyrifos, 2,4-D, and glyphosate on the common toad Rhinella arenarum (Anura: Bufonidae). Water Air Soil Pollut 226

Lal B, Sarang MK, Kumar P (2013) Malathion exposure induces the endocrine disruption and growth retardation in the catfish, Clarias batrachus (Linn.). Gen Compar Endocrinol 181:139-145

Lazartigues A, Thomas M, Banas D, Brun-Bellut J, Cren-Olivé C, Feidt C (2013) Accumulation and half-lives of 13 pesticides in muscle tissue of freshwater fishes through food exposure. Chemosphere 91:530-535

Li J, Li Y, Lu J (2009) Adsorption of herbicides 2,4-D and acetochlor on inorganic-organic bentonites. Appl Clay Sci 46:314-318

Li K, Wu J-Q, Jiang L-L, Shen L-Z, Li J-Y, He Z-H, Wei P, Lv Z, He M-F (2017) Developmental toxicity of 2,4-dichlorophenoxyacetic acid in zebrafish embryos. Chemosphere 171:40-48

Liaud C, Brucher M, Schummer C, Coscolla C, Wolff H, Schwartz J, Yusa V, Millet M (2016) Utilization of long duration high-volume sampling coupled to SPME-GC-MS/MS for the assessment of airborne pesticides variability in an urban area (Strasbourg, France) during agricultural applications. J Environ Sci Health 0:1-12

Loos R, Locoro G, Comero S, Contini S, Schwesig D, Werres F, Balsaa P, Gans O, Weiss S, Blaha L, Bolchi M, Gawlik BM (2010) PanEuropean survey on the occurrence of selected polar organic persistent pollutants in ground water. Water Res 44:4115-4126

Lowry OH, Rosebrough NJ, Farr AL, Randall RJ (1951) Protein measurement with the Folin phenol reagent. J Biol Chem 193:265-275

Lushchak VI (2011) Environmentally induced oxidative stress in aquatic animals. Aquat Toxicol 101:13-30

Madriagal-Bujaidar E, Hernández-Ceruelos A, Chamorro G (2001) Induction of sister chromatid exchanges by 2,4dichlorophenoxyacetic acid in somatic and germ cells of mice exposed in vivo. Food Chem Toxicol 39:941-946
Mann RM, Bidwell JR (1999) The toxicity of glyphosate and several glyphosate formulations to four species of southwestern Australian frogs. Arch Environ Contam Toxicol 36:193-199

Mansano AS, Moreira RA, Dornfeld HC, Diniz LGR, Vieira EM, Daam MA, Rocha O, Seleghim MHR (2016a) Acute and chronic toxicity of diuron and carbofuran to the Neotropical cladoceran Ceriodaphnia silvestrii. Environ Sci Pollut Res 25:13335-13346. https://doi.org/10.1007/s11356-016-8274-9

Mansano AS, Moreira RA, Pierozzi M, Oliveira TM, Vieira EM, Rocha O, Regali-Seleghim MH (2016b) Effects of diuron and carbofuran pesticides in their pure and commercial forms on Paramecium caudatum: the use of protozoan in ecotoxicology. Environ Pollut 213:160-172

Martínez-Tabche L, Madriagal-Bujaidar E, Negrete T (2004) Genotoxicity and lipoperoxidation produced by paraquat and 2,4dichlorophenoxyacetic acid in the gills of rainbow trout (Oncorhynchis mikiss). Bull Environ Contam Toxicol 73

Martins M, Costa PM (2017) The comet assay in aquatic (eco)genotoxicity using non-conventional model organisms: relevance, constrains and prospects. In: Larramendy ML (ed) Ecotoxicology and genotoxicology: non-traditional aquatic models. The Royal Society of Chemistry, Cambridge, pp 3-32

Mastrángelo MM, Ferrari L (2013) Cnesterodon decemmaculatus juveniles as test organisms in toxicity assessment: cadmium case. Bull Environ Contam Toxicol 91:49-54

Matviishyn TM, Kubrak OI, Husak VV, Storey KB, Lushchak VI (2014) Tissue-specific induction of oxidative stress in goldfish by $2,4-$ dichlorophenoxyacetic acid: mild in brain and moderate in liver and kidney. Environ Toxicol Pharmacol 37:861-869

Meffe R, de Bustamante I (2014) Emerging organic contaminants in surface water and groundwater: a first overview of the situation in Italy. Sci Total Environ 481:280-295

Mela M, Guiloski IC, Doria HB, Randi MA, de Oliveira Ribeiro CA, Pereira L, Maraschi AC, Prodocimo V, Freire CA, Silva de Assis HC (2013) Effects of the herbicide atrazine in neotropical catfish (Rhamdia quelen). Ecotoxicol Environ Saf 93:13-21

Menéndez-Helman RJ, Ferreyroa GV, Dos Santos AM, Salibián A (2012) Glyphosate as an acetylcholinesterase inhibitor in Cnesterodon decemmaculatus. Bull Environ Contam Toxicol 88:6-9

Menéndez-Helman RJ, Ferreyroa GV, dos Santos AM, Salibián A (2015) Circannual rhythms of acetylcholinesterase (AChE) activity in the freshwater fish Cnesterodon decemmaculatus. Ecotoxicol Environ Saf 111:236-241

Menni RC, Gómez SE, López Armengol F (1996) Subtle relationships: freshwater fishes and the chemistry of water in southern South America. Hydrobiologia 328:173-197

Molinari G, Kujawski M, Scuto A, Soloneski S, Larramendy ML (2013) DNA damage kinetics and apoptosis in ivermectin-treated Chinese hamster ovary (CHO-K1) cells. J Appl Toxicol 33:1260-1267

Muthulakshmi S, Maharajan K, Habibi HR, Kadirvelu K, Venkataramana M (2018) Zearalenone induced embryo and neurotoxicity in zebrafish model (Danio rerio) role of oxidative stress revealed by a multi biomarker study. Chemosphere 198:111-121

Naqvi G-Z, Shoaib N, Ali AM (2017) Pesticides impact on protein fish (Oreochromis mossambicus) tissues. Indian J Geo Marine Sci 49: 1864-1868

Newman MC, Clements WH (2008) Ecotoxicology. A comprehensive treatment. CRC Press, Boca Ratón, FL, 852 pp

Nikoloff N, Natale GS, Marino D, Soloneski S, Larramendy ML (2014) Flurochloridone-based herbicides induced genotoxicity effects on Rhinella arenarum tadpoles (Anura: Bufonidae). Ecotoxicol Environ Saf 100:275-281

Nunes B, Carvahlo F, Guilhermino L (2005) Characterization and use of the total head soluble cholinesterases from mosquitofish (Gambusia holbrooki) for screening of anticholinesterase activity. J Enzyme Inhib Med Chem 20:369-376 
Oruç EO, Üner N (2000) Combined effects of 2,4-D and azinphosmethyl on antioxidant enzymes and lipid peroxidation in liver of Oreochromis niloticus. Compar Biochem Physiol C 127:291-296

Oruç EO, Üner N (2002) Marker enzyme assessment in the liver of Cyprinus carpio (L.) exposed to 2,4-D and azinphosmethyl. J Biochem Mol Toxicol 16:182-188

Oruç EO, Sevgiler Y, Üner N (2004) Tissue-specific oxidative stress responses in fish exposed to 2,4-D and azinphosmethyl. Compar Biochem Physiol C 137:43-51

Ossana NA, Eissa BL, Baudou FG, Castañé PM, Soloneski S, Ferrari L (2016) Multibiomarker response in ten spotted live-bearer fish Cnesterodon decemmaculatus (Jenyns, 1842) exposed to Reconquista river water. Ecotoxicol Environ Saf 133:73-81

Ozcan Oruç E, Uner N, Sevgiler Y, Usta D, Durmaz H (2006) Sublethal effects of organophosphate diazinon on the brain of Cyprinus carpio. Drug Chem Toxicol 29:57-67

Pamela CC, Richard AH (1994) Biochemistry. Libbincott's Illustrated Reviews. Lippencot-Raven Publishers, Philadelphia, PA, 443 pp

Paulino MG, Souza NES, Fernandes MN (2012) Subchronic exposure to atrazine induces biochemical and histopathological changes in the gills of a Neotropical freshwater fish, Prochilodus lineatus. Ecotoxicol Environ Saf 80:6-13

Peixoto FP, Gomes-Laranjo J, Vicente JA, Madeira VMC (2008) Comparative effects of the herbicides dicamba, 2,4-D and paraquat on non-green potato tuber calli. J Plant Physiol 165:1125-1133

Pérez-Iglesias JM, Ruiz de Arcaute C, Nikoloff N, Dury L, Soloneski S, Natale GS, Larramendy M (2014) The genotoxic effects of the imidacloprid-based insecticide formulation Glacoxan Imida on Montevideo tree frog Hypsiboas pulchellus tadpoles (Anura, Hylidae). Ecotoxicol Environ Saf 104:120-126

Pérez-Iglesias JM, Ruiz de Arcaute C, Natale GS, Soloneski S, Larramendy ML (2017) Evaluation of imazethapyr-induced DNA oxidative damage by alkaline Endo III- and Fpg-modified singlecell gel electrophoresis assay in Hypsiboas pulchellus tadpoles (Anura, Hylidae). Ecotoxicol Environ Saf 142:503-508

Persch TSP, Weimer RN, Freitas BS, Oliveira GT (2017) Metabolic parameters and oxidative balance in juvenile Rhamdia quelen exposed to rice paddy herbicides: Roundup®, Primoleo®, and Facet®. Chemosphere 174:98-109

Pitarque M, Creus A, Marcos R, Hughes JA, Anderson D (1999) Examination of various biomarkers measuring genotoxic endpoints from Barcelona airport personnel. Mutat Res 440:195-204

Poletta GL, Simoniello MF, Mudry MD (2016) Biomarkers of oxidative damage and antioxidant defense capacity in Caiman latirostris blood. Compar Biochem Physiol C 179:29-36

Rao KS, Moorthy KS, Reddy BK, Swami KS, Chetty CS (1987) Effect of benthiocarb on protein metabolism of freshwater teleost Sarotherodon mossambicus. Indian J Environ Health 29:45-51

Rodríguez-Fuentes G, Rubio-Escalante FJ, Noreña-Barroso E, EscalanteHerrera KS, Schlenk D (2015) Impacts of oxidative stress on acetylcholinesterase transcription, and activity in embryos of zebrafish (Danio rerio) following chlorpyrifos exposure. Compar Biochem Physiol C 172-173:19-25

Romero-Puertas MC, Rodríguez-Serrano M, Corpas FJ, Gómez M, Del Rio LA, Sandalio LM (2004) Cd-induced subcellular accumulation of $\mathrm{O}_{2}{ }^{--}$and $\mathrm{H}_{2} \mathrm{O}_{2}$ in pea leaves. Plant Cell Environ 27:1122-1134

Ruiz de Arcaute C, Pérez-Iglesias JM, Nikoloff N, Natale GS, Soloneski S, Larramendy M (2014a) Genotoxicity evaluation of the insecticide imidacloprid on circulating blood cells of Montevideo tree frog Hypsiboas pulchellus tadpoles (Anura, Hylidae) by comet and micronucleus bioassays. Ecol Indic 45:632-639

Ruiz de Arcaute C, Soloneski S, Larramendy M (2014b) Evaluation of the genotoxicity of a herbicide formulation containing 3,6-dichloro2-metoxybenzoic acid (dicamba) in circulating blood cells of the tropical fish Cnesterodon decemmaculatus. Mutat Res 773:1-8
Ruiz de Arcaute C, Soloneski S, Larramendy M (2016) Toxic and genotoxic effects of the 2,4-dichlorophenoxyacetic acid (2,4-D)based herbicide on the Neotropical fish Cnesterodon decemmaculatus. Ecotoxicol Environ Saf 128:222-229

Salbego J, Pretto A, Gioda CR, Cavalheiro de Menezes C, Lazzari R, Radunz J, Baldisseriotto B, Loro VL (2010) Herbicide formulation with glyphosate affects growth, acetylcholinesterase activity, and metabolic and haematological parameters in piava (Leporinus obtusidens). Arch Environ Contam Toxicol 58:740-745

Samanta P, Pal S, Mukherjee AK, Ghosh AR (2014) Biochemical effects of glyphosate based herbicide, Excel Mera 71 on enzyme activities of acetylcholinesterase (AChE), lipid peroxidation (LPO), catalase (CAT), glutathione-S-transferase (GST) and protein content on teleostean fishes. Ecotoxicol Environ Saf 107:120-125

Sancho E, Ferrando MD, Andreu E (1997) Sublethal effects of an organophosphate insecticide on the European eel, Anguilla anguilla. Ecotoxicol Environ Saf 36:57-65

Sapana Devi M, Gupta A (2014) Sublethal toxicity of commercial formulations of deltamethrin and permethrin on selected biochemical constituents and enzyme activities in liver and muscle tissues of Anabas testudineus. Pest Biochem Physiol 115:48-52

Seshagiri R, Sreenivasa MK, Reddy KB, Sreeramulu CC (1987) Effect of benthiocarb on protein metabolism of freshwater teleost Sarotherodon mossambicus. Indian J Environ Health 29:45-51

Soloneski S, Larramendy M (2010) Sister chromatid exchanges and chromosomal aberrations in Chinese hamster ovary (CHO-K1) cells treated with insecticide pirimicarb. J Hazard Mater 174:410-415

Soloneski S, Larramendy ML (2017) The use of the ten spotted livebearer fish Cnesterodon decemmaculatus (Jenyns, 1842) (Pisces, Poeciliidae) in the genotoxic evaluation of environmental pollutants. In: Larramendy ML (ed) Ecotoxicology and genotoxicology-nontraditional aquatic models. The Royal Society of Chemistry, London, pp 327-346

Soloneski S, Nikoloff N, Larramendy ML (2016) Analysis of possible genotoxicity of the herbicide flurochloridone and its commercial formulations: Endo III and Fpg alkaline comet assays in Chinese hamster ovary (CHO-K1) cells. Mutat Res 797:46-52

Soloneski S, Ruiz de Arcaute C, Nikoloff N, Larramendy ML (2017) Genotoxicity of the herbicide imazethapyr in mammalian cells by oxidative DNA damage envaluation using the Endo III and Fpg alkaline comet assays. Environ Sci Pollut Res 24:10292-10300

Sorensen KC, Stucki JW, Warner ED, Wagner ED, Plewa MJ (2005) Modulation of the genotoxicity of pesticides reacted with redoxmodified smectite clay. Environ Mol Mutagen 46:174-181

Stara A, Machova J, Velisek J (2012) Effect of chronic exposure to simazine on oxidative stress and antioxidant response in common carp (Cyprinus carpio L.). Environ Toxicol Pharmacol 33:334-343

Summerfelt RC, Smith LS (1990) Anaesthesia, surgery and related techniques. In: Schreck CB, Moyle PB (eds) Methods for fish biology. American Fisheries Society, Bethesda MD, pp 213-272

Tagert MLM, Massey JH, Shaw DR (2014) Water quality survey of Mississippi's Upper Pearl River. Sci Total Environ 481:564-573

Topal A, Alak G, Altun S, Erol HS, Atamanalp M (2017) Evaluation of 8hydroxy-2-deoxyguanosine and NFkB activation, oxidative stress response, acetylcholinesterase activity, and histopathological changes in rainbow trout brain exposed to linuron. Environ Toxicol Pharmacol 49:14-20

Tripathi G, Singh H (2013) Impact of alphamethrin on biochemical parameters of Channa punctatus. J Environ Biol 34:227-230

Tripathi G, Verma P (2004a) Endosulfan-mediated biochemical changes in the freshwater fish Clarias batrachus. Biomed Environ Sci 17: $47-56$

Tripathi G, Verma P (2004b) Fenvalerate-induced changes in a catfish, Clarias batrachus: metabolic enzymes, RNA and protein. Compar Biochem Physiol C 138:75-79 
Ullah R, Zuberi A, Ullah S, Ullah I, Ullah Dawar F (2014) Cypermethrin induced behavioral and biochemical changes in mahseer, Tor putitora. J Toxicol Sci 39:829-836

USEPA (2005) Reregistration Eligibility Decision (RED) for 2,4 D. In: 738-R-05-002. U.S. Environmental Protection Agency, Washington DC

USEPA (2006) Reregistration eligibility decision for dicamba and associated salts. U.S. Environmental Protection Agency, Washington DC https://archive.epa.gov/pesticides/reregistration/web/pdf/ dicamba_red.pdf

USEPA (2017) Pesticides industry sales and usage. 2008-2012 Market estimates, vol 24. U.S. Environmental Protection Agency, Washington DC

Valavanidis A, Vlahogianni T, Dassenakis M, Scoullos M (2006) Molecular biomarkers of oxidative stress in aquatic organisms in relation to toxic environmental pollutants. Ecotoxicol Environ Saf 64:178-189

Valko M, Rhodes CJ, Moncol J, Izakovic M, Mazur M (2006) Free radicals, metals and antioxidants in oxidative stress-induced cancer. Chem Biol Interact 160:1-40

van der Oost R, Beyer J, Vermeulen NPE (2003) Fish bioaccumulation and biomarkers in environmental risk aseessment: a review. Environ Toxicol Pharmacol 13:57-149

Varó I, Amat F, Navarro JC (2008) Acute toxicity of dichlorvos to Aphanius iberus (Cuvier \& Valenciennes, 1846) and its anticholinesterase effects on this species. Aquat Toxicol 88:53-61
Vera-Candioti J, Soloneski S, Larramendy ML (2011) Acute toxicity of chromium on Cnesterodon decemmaculatus (Pisces: Poeciliidae). Theoria 1:81-88

Vera-Candioti J, Soloneski S, Larramendy ML (2013) Single-cell gel electrophoresis assay in the ten spotted live-bearer fish, Cnesterodon decemmaculatus (Jenyns, 1842), as bioassay for agrochemical-induced genotoxicity. Ecotoxicol Environ Saf 98: 368-373

Wang XH, Souders CL, Zhao YH, Martyniuk CJ (2018) Mitochondrial bioenergetics and locomotor activity are altered in zebrafish (Danio rerio) after exposure to the bipyridylium herbicide diquat. Toxicol Lett 283:13-20

WHO (2009) The WHO recommended classification of pesticides by hazard and guidelines to classification: 2009. World Health Organization, Geneva, Switzerland, $81 \mathrm{pp}$

Ye J, Wu H, Wu Y, Wang C, Zhang H, Shi X, Yang J (2012) High molecular weight hyaluronan decreases oxidative DNA damage induced by EDTA in human corneal epithelial cells. Eye 26:10121020

Zar JH (2010) Biostatistical analysis, vol 960. Prentice Hall, New Jersey

Publisher's note Springer Nature remains neutral with regard to jurisdictional claims in published maps and institutional affiliations. 